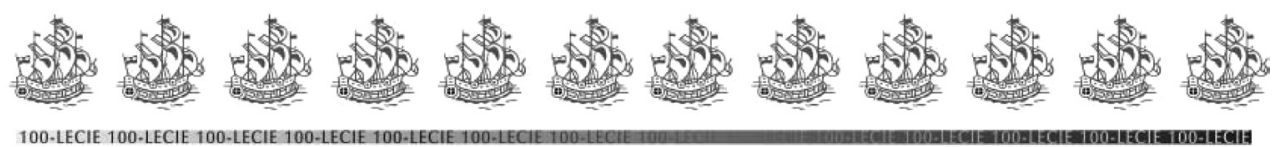

SzKola GtóWNa Handlowa w WARSzAWIE 1906 - 2006 WARSAW SCHOOl Of ECONOMICS

Zbigniew LANDAU*

\title{
Andrzej Grodek (1901-1959)
}

Andrzej Grodek był jednym z przedstawicieli już dziś zanikłej generacji, której przedstawiciele całkowicie identyfikowali się z instytucjami, w których pracowali i działali. Nie były to - jak dziś - związki opierające się przede wszystkim na umowie o pracę, ale powiązania natury emocjonalnej powodujące, że ludzie całe dorosłe życie poświęcali działalności i rozwojowi placówek, z którymi czuli się związani. Były to przy tym związki na dobre i na złe. Jeżeli coś zaczynało psuć się w „ich” instytucji, to nie szukali nowego miejsca pracy, ale starali się wyprowadzić macierzystą instytucję na możliwie spokojne wody. Życie osobiste, kariery, przyjaźnie tych ludzi koncentrowały się wokół miejsca ich działalności. Jednym z klasycznych przykładów ludzi, którzy poświęcili się takiej działalności był właśnie Andrzej Grodek - człowiek Szkoły Głównej Handlowej¹.

Z Wyższą Szkołą Handlową (poprzedniczką SGH) związał się w wieku 20 lat po uzyskaniu świadectwa dojrzałości w łódzkiej Szkole Realnej Zgromadzenia Kupców. Po dwóch latach studiów zmuszony został, ze względu na trudną sytuację materialną, do ich przerwanie i podjęcia pracy w Fabryce Sztucznego Jedwabiu w Warszawie. Następnie pracował jako nauczyciel na kursach handlowych w Wieruszowie. Poprawa sytuacji finansowej pozwoliła Andrzejowi Grodkowi na powrót na studia w 1925 r., które jednak łączył już z pracą zarobkową. W tym okresie

Autor jest pracownikiem Szkoły Głównej Handlowej w Warszawie. Artykuł wpłynął do redakcji w lutym 2006 r.

1 O A. Grodku pisało już wielu autorów. Tu przykładowo wymienimy kilka najważniejszych opracowań: H. Balicka-Kozłowska, Andrzej Grodek a Instytut Gospodarstwa Społecznego, „Biuletyn IGS” 1968, nr 1, s. 13-22; S. Berezowski, Rektor Andrzej Grodek. W 25 rocznice śmierci, „Kronika Warszawy” 1984, nr 4, s. 9-20; J. Ciepielewski, I. Kostrowicka, Z. Landau, J. Tomaszewski, Przedmowa do: A. Grodek, Wybór pism w dwóch tomach, Warszawa 1963, t. I, s. 5-19; I. Kostrowicka, Andrzej Grodek jako historyk i ekonomista, „Zeszyty Naukowe SGPiS” 1960, nr 19, s. 3-7; W. Kula, Andrzej Grodek (1901-1959), „Kwartalnik Historyczny” 1959, nr 4, s. 1388-1392; W. Kula, Grodek Andrzej, „Polski Słownik Biograficzny” t. VIII, s. 610-612; M.W. Mróz, Andrzej Grodek (1901-1959), [w:] Poczet wybitnych profesorów SGH-SGPiS 1906-1986, Warszawa 1986, s. 34-58; W. Mróz, Andrzej Grodek. W czterdziesta rocznice śmierci, „Gazeta SGH” 1 XII 1999. 
studia w Wyższej Szkole Handlowej były dwustopniowe. Pierwsze trzy lata kończyły się napisaniem pracy dyplomowej i zdaniem wymaganych egzaminów. Studia magisterskie trwały jeden rok, w trakcie którego należało napisać pracę magisterską i zdać egzaminy.

Andrzej Grodek powrócił na trzeci rok studiów. Pracę dyplomową napisał pod kierunkiem profesora Ludwika Krzywickiego. Był to uczony o ogromnej erudycji i niezwykle szerokich zainteresowaniach badawczych. Na prowadzone przez niego seminaria na ogół było mało chętnych, gdyż studenci starali się wybierać zajęcia o tematyce bardziej ułatwiającej im start w pracy zawodowej. Seminaria Ludwika Krzywickiego nie miały tego charakteru i dlatego zapisywali się na nie tylko pojedynczy studenci. Nie wiem o ile jest to prawdą, ale podobno na seminarium magisterskim Ludwika Krzywickiego, Andrzej Grodek był jedynym słuchaczem. Andrzeja Grodka w tym okresie interesowały problemy historii pieniądza i instytucji bankowych. Stąd praca dyplomowa traktowała o „Pieniądzach papierowych podczas insurekcji 1794 r.” Została obroniona w 1925 r. a następnie ogłoszona drukiem $^{2}$. Autor przy jej pisaniu oparł się przede wszystkim na materiałach archiwalnych, w mniejszym stopniu zaś na dość ubogiej literaturze przedmiotu. Dziśs kiedy archiwa, z których korzystał uległy całkowitemu zniszczeniu w czasie powstania warszawskiego, praca Andrzeja Grodka jest jedynym naukowo wiarygodnym opracowaniem tego zagadnienia.

W roku akademickim 1926/27 kontynuował studia w Wyższej Szkole Handlowej, ale dyplom magistra uzyskał dopiero w 1931 r. Jesienią 1926 r. na podstawie referencji wystawionych mu przez promotora pracy dyplomowej Ludwika Krzywickiego uzyskał stanowisko asystenta przy Katedrze Historii Handlu. Było to duże wyróżnienie, bo liczba asystentów w Szkole była bardzo ograniczona i zostawali nimi tylko najzdolniejsi studenci. Asystenturę Andrzej Grodek łączył przez pewien czas z sekretarzowaniem w Towarzystwie Ekonomistów i Statystyków Polskich oraz w redakcji kwartalnika „Ekonomista” będącego organem Towarzystwa. Oba ostatnie zajęcia przerwało powołanie do służby wojskowej w 1929 r. (wcześniej ochotniczo służył w Wojsku Polskim w okresie od sierpnia do grudnia 1920 r. i został wtedy ranny).

Po powrocie z wojska Andrzej Grodek otrzymał stypendium na uzupełniające studia we Francji. W okresie międzywojennym Szkoła starała się, aby kandydaci na asystentów oraz asystenci mieli możność otarcia się o zagraniczne czołowe ośrodki naukowe. Dawało to bowiem młodym adeptom nauki możliwość poszerzenia horyzontów naukowych, wyjścia z pewnego zaścianka jakim w tym okresie znajdowała się jeszcze polska ekonomia, zetknięcie się z innymi ludźmi i innymi poglądami. Pozwalało to też na perfekcyjne opanowanie znajomości języków obcych. Andrzej Grodek na półtora roku trafił na Wydział Prawa Sorbony. Poza studiami zbierał tam m.in. materiały do przyszłych rozpraw naukowych. Ze studiów we Francji wrócił jesienią 1931 r. i został asystentem naukowym w Bibliotece Wyższej Szkoły Handlowej; później awansował na zastępcą dyrektora. W trakcie

2 „Roczniki Wyższej Szkoły Handlowej” 1927, s. 67-152. Odbitka: Warszawa 1927, s. 85. 
pobytu we Francji napisał, również pod kierunkiem Ludwika Krzywickiego, pracę magisterską pt. „Zagadnienie emisji znaków pieniężnych w Księstwie Warszawskim (1806-1813)"3, a w trakcie pobytu w Polsce zdał wymagane regulaminem studiów egzaminy i uzyskał stopień magistra. Egzaminy magisterskie nie były wówczas tak łatwe jak obecnie. W Wyższej Szkole Handlowej obowiązywała zasada, że zdawało się jednego dnia egzaminy z trzech przedmiotów, przy czym do każdego $\mathrm{z}$ nich student $\mathrm{w}$ porozumieniu $\mathrm{z}$ właściwym profesorem ustalał zakres tematyczny i przygotowywał tezy do wytypowanych zagadnień. Andrzej Grodek zdawał ekonomię polityczną (przy czym egzamin dotyczył inflacji kredytu, polityki banków emisyjnych i ich wpływu na ceny oraz teorii wartości pieniądza), historię doktryn ekonomicznych (doktryna kanoniczna, teoria materializmu dziejowego, pieniądze papierowe w Polsce) oraz historię gospodarczą (historia bankierstwa, położenie gospodarcze Polski w latach 1764-1815 i stosunki handlowe Królestwa Polskiego z państwami ościennymi $)^{4}$. Przy czym był ściśle określony limit czasowy egzaminu, który nie mógł trwać krócej niż przewidywały to regulaminy WSH.

Praca w Bibliotece na stanowisku asystenta pozwoliła Andrzejowi Grodkowi na zbliżenie się do dyrektora Biblioteki, którym był profesor Konstanty Krzeczkowski. Należał on - podobnie jak Ludwik Krzywicki - do najwybitniejszych znawców problematyki społecznej w Polsce. Obaj profesorowie, których uczniem był Andrzej Grodek, mieli pewien wpływ i na jego zainteresowania naukowe i na wypracowanie metodologii badań. Krzywickiego pociągały duże syntezy, gdy Krzeczkowskiego raczej pewne szperactwo. Obie te cechy widoczne są w twórczości ich ucznia.

Związanie się z Biblioteką dało Andrzejowi Grodkowi możliwość zapoznania się zarówno z polską, jak i światową literaturą ekonomiczną. Biblioteka prowadzona była z rozmachem, Szkoła nie szczędziła pieniędzy na zakup książek i prenumeratę czasopism, stąd jej księgozbiór w zakresie nauk ekonomicznych i społecznych uważany był za jeden z największych nie tylko w Polsce, ale w całej Europie Środkowo-Wschodniej.

W latach 1931-1939 Andrzej Grodek z jednej strony prowadził własne prace badawcze, m.in. napisał rozprawy doktorską i habilitacyjną, a z drugiej opracował imponujący katalog przedmiotowy zbiorów ekonomicznych Biblioteki Szkoły Głównej Handlowej5. Ukazał się on dopiero po wojnie, ale zasadniczą jego cześć wydrukowano jeszcze w 1939 r. Katalog ten, praktycznie rzecz biorąc, był prawie kompletną bibliografią polskiego, i częściowo zagranicznego, piśmiennictwa ekonomicznego. Jego opracowanie wymagało od autora wzięcia do ręki każdej uwzględnionej w katalogu książki i zaklasyfikowania jej do określonego działu. Aby bowiem nie powiększać nadmiernie i tak ogromnej objętości katalogu, jego twórca zdecydował się, że każda publikacja uwzględniana będzie tylko w jednym dziale, bez stosowania odsyłaczy. To jednak narzucało autorowi konieczność opracowania niezwykle wnikliwego klasyfikowania poszczególnych pozycji. Jeżeli bowiem

\footnotetext{
Warszawa 1934, SGH, s. 143.

4 Cyt. wg M.W. Mróz, Andrzej Grodek, [w:] Poczet..., s. 35-36.

5 Katalog Biblioteki. I. Nauki ekonomiczne i handlowe, Warszawa 1939-1945, SGH, s. 941.
} 
publikacja zostałaby źle zaklasyfikowana, to praktycznie nie można byłoby jej odnaleźć w katalogu. Dzięki tej pracy Andrzejowi Grodkowi danym było poznanie całego ogromnego już wówczas księgozbioru Biblioteki, a jego katalog do dziś spełnia rolę przewodnika po polskiej literaturze ekonomicznej powstałej przed drugą wojną światową. Pod tym względem do dziś jest niezastąpionym źródłem informacji bibliograficznych.

Lata poprzedzające wybuch drugiej wojny światowej były okresem największej aktywności naukowej Andrzeja Grodka. Przede wszystkim w 1935 r. uzyskał stopień doktora nauk ekonomicznych na podstawie książki „Piotr Maleszewski (1767-1828) i jego nauka społeczna”. Rok później na podstawie pracy „Idea Banku Narodowego (geneza Banku Polskiego) 1763-1828"7 uzyskał habilitację i stanowisko docenta, a tym samym prawo do samodzielnego prowadzenia wykładów $\mathrm{z}$ historii handlu, przy czym historia handlu traktowana była szeroko i praktycznie odpowiadała zakresem wykładowi historii gospodarczej. Obie publikacje wskazywały na wzrost zainteresowania Andrzeja Grodka polską myślą ekonomiczną, bo obie traktowały o tym problemie. Zainteresowanie Piotrem Maleszewskim wzbudził w Andrzeju Grodku, Konstanty Krzeczkowski. W książce o Maleszewskim autor wykorzystał nieznane wcześniej rękopisy autora, których odnalezienie we Francji stanowiło już znaczny wyczyn. Papiery znajdowały się bowiem w rękach prawnuka córki Piotra Maleszewskiego, ale ustalenie tego faktu nie było wcale proste. Do części spuścizny rękopiśmiennej Maleszewskiego nie udało się Andrzejowi Grodkowi dotrzeć, gdyż francuscy posiadacze tych papierów nie byli skłonni do ich udostępnienia ${ }^{8}$. Mimo tych trudności i sporych luk w życiorysie Piotra Maleszewskiego udało się przedstawić jego poglądy i tym samym ocalić je przed zapomnieniem.

Rozprawa habilitacyjna stanowiła w pewnym stopniu kontynuację wcześniejszych badań nad instytucjami finansowymi. Ale tu autora, w znacznie większym stopniu niż sama instytucja banku centralnego i jego funkcjonowanie, interesowały poglądy na temat celowości powołania i kierunków działalności banku centralnego wyrażane w polskiej literaturze ekonomicznej i politycznej. W załączniku wymienione i omówione zostay 174 projekty i głosy dotyczące powołania banku i emisji papierowych znaków pieniężnych napisanych przed 1828 r. Dla wielu $\mathrm{z}$ tych projektów jest to dziś jedyny ślad ich istnienia.

Praca w Szkole Głównej Handlowej skupiała główne zainteresowanie młodego naukowca. Dużo pisał, prowadził zajęcia ze studentami, aktywnie działał w Bibliotece, gdzie obok przygotowywania drukowanego katalogu zbiorów opracował na wzór biblioteki London School of Economics schemat katalogu rzeczowego, który w zmienionej formie do dziś istnieje w Bibliotece SGH. Wykładał też w Instytucie Pedagogicznym Związku Nauczycielstwa Polskiego, działał w Instytucie Gospodarstwa Społecznego. W tym okresie wykładanie przez pracowników SGH

\footnotetext{
6 Warszawa 1936, SGH, s. 182.

7 Warszawa 1936, SGH, s. 95.

8 A. Grodek, Puścizna rękopiśmienna Piotra Maleszewskiego, „Roczniki Dziejów Społecznych i Gospodarczych"1932-1933, s. 141-144.
} 
w innych uczelniach było zjawiskiem normalnym, podobnie jak dwuetatowość. Władze Szkoły uważały, że rozszerza to horyzonty pracowników, pogłębia ich wiedzę teoretyczną i pozwala zgromadzić doświadczenia praktyczne, a wszystko to procentuje w formie coraz lepszej dydaktyki. Szkoła nie godziła się jedynie na dwuetatowość asystentów, ale to wynikało z niezwykle krótkich terminów przeznaczonych na pisanie prac doktorskiej i habilitacyjnej. Habilitacja miała być przeprowadzana w rok po doktoracie. Służyło to niezwykle ostrej selekcji kandydatów na pracowników naukowych. Trzeba było łączyć pracowitość z dużą wiedzą i umiejętnością podejmowania nowych tematów.

Wybuch wojny we wrześniu 1939 r. zastał Andrzeja Grodka na stanowisku wicedyrektora Biblioteki. Zgłosił się wówczas ochotniczo do Robotniczych Batalionów Obrony Warszawy. Po kapitulacji miasta dyrektor Biblioteki Konstanty Krzeczkowski został aresztowany przez Niemców i niedługo po wypuszczeniu z więzienia zmarł w 1939 r. W tym stanie rzeczy Grodek poczuł się odpowiedzialny za Bibliotekę. Jej sytuacja była trudna, bo okupant zlikwidował SGH. W jej miejsce powstała średnia Miejska Szkoła Handlowa, gdzie Andrzej Grodek prowadził wykłady z historii gospodarczej, ale Szkoła nie była formalnie kontynuacją SGH, a tym samym nie miała żadnego prawa do Biblioteki. Niemcy nie byli zainteresowani zbiorami i zamierzali usunąć je z budynku przy Rakowieckiej i przenieść do magazynów Biblioteki Ordynacji Krasińskich na Okólniku (magazyny te wraz z książkami zostały spalone przez Niemców po powstaniu warszawskim). Andrzejowi Grodkowi udało się jednak wraz z dyrektorem Biblioteki Narodowej, która mieściła się w tym samym gmachu co Biblioteka SGH, uzyskać zgodę na pozostawienie księgozbioru na miejscu. Równocześnie Biblioteka SGH potraktowana została jako zbiór zabezpieczony pod zarządem II Oddziału Staatsbibliothek. Andrzej Grodek został kierownikiem zbiorów i wbrew wprowadzonemu przez okupanta zakazowi udostępniania książek, starał się iść na rękę ludziom nielegalnie pracującym naukowo. Udostępniał im zbiory i wypożyczał książki. Dodatkowo gmach Biblioteki stał się miejscem spotkań i dyskusji naukowców oraz polityków. Podobno ukrywali się tam poszukiwani przez Niemców działacze polityczni i Żydzi. Było to związane z ogromnym ryzykiem osobistym, ale kierownik Biblioteki z tym się nie liczył. W tym okresie aktywność naukowa Andrzeja Grodka słabnie. Miał na utrzymaniu rodzinę, musiał dbać o Bibliotekę, związany był z nielegalnym Uniwersytetem Zachodnim. Prowadził jednak studia dotyczące praw Polski do terenów zachodnich. Publikacje na ten temat ukazały się w 1945 r.9. Z większych

9 A. Grodek, Zagadnienie kolonizacji miejskiej na Ziemiach Odzyskanych, „Przegląd Zachodni” 1945, nr 1, s. 27-38; razem z M. Kiełczewską, Odra-Nysa najlepsza granica Polski. Poznań 1945 Instytut Zachodni, s. 65 (II wydanie w 1946 r.). Inne prace pozostały w formie maszynopisów i są obecnie przechowywane w Archiwum Polskiej Akademii Nauk (np. Uwagi do polityki produkcji i osadnictwa rolnego na ziemiach nowych. Druk [w:] A. Grodek, Wybór..., t. II, s. 395-403). 
opracowań z okresu wojny zachowała się praca „Żywioł obcy w przemyśle, górnictwie, finansach i handlu Polski. Próba ujęcia statystycznego"10.

Powstanie warszawskie spowodowało nowe zagrożenie dla Biblioteki. Po opanowywaniu poszczególnych dzielnic, Niemcy zarządzali opuszczenie ich przez wszystkich mieszkańców. Podporządkowanie się temu oznaczałoby pozostawienie zbiorów bibliotecznych samym sobie. W tej sytuacji Andrzej Grodek i dyrektor Biblioteki Narodowej Józef Grycz z żoną postanowili pozostać w gmachu biblioteki w celu jej ochrony. Okazało się to zbawienne. Niemcy bowiem niszczyli kolejne budynki w mieście. Podpalili m.in. gmach „A” Szkoły Głównej Handlowej, w którym zostały zgromadzone w czasie wojny zbiory Archiwum Akt Nowych. Po podpaleniu tego budynku, zamierzali spalić gmach biblioteczny wraz ze zbiorami. Andrzej Grodek i Józef Grycz podjęli próbę przekonania, że w gmachu znajdują się zbiory cenne dla kultury niemieckiej i że w związku z tym nie należy ich niszczyć. Niemcy postanowili wstrzymać się z podpaleniem budynku, ale nakazali Gryczom i Grodkowi natychmiastowe opuszczenie miasta. Andrzej Grodek czuł się jednak nadal odpowiedzialny za los Biblioteki. Dlatego uciekł z transportu wiozącego go do obozu przejściowego w Pruszkowie. Stwarzało to bowiem jakąś nikłą szansę ratowania zbiorów. W związku z tym, że udało się kierownictwu Rady Głównej Opiekuńczej uzyskać od Niemców zgodę na wywiezienie z Warszawy części ocalałych zasobów bibliotecznych, Andrzej Grodek zorganizował ekipę, która przygotowywała najcenniejsze książki do wywiezienia z miasta. Do transportu przygotowywano pakując je do worków ${ }^{11}$.

Wobec tego, że Andrzej Grodek starał się być jak najbliżej Warszawy, znalazł się w niej już w dniu ucieczki Niemców. Zastał gmach Biblioteki cały. Zaczął więc przygotowywania do jej uruchomienia, co udało się w końcu lutego. Stopniowo wracali do Warszawy pracownicy Szkoły. Stwarzało to szanse na jej reaktywowanie. W tym kierunku nieustannie działał Andrzej Grodek. Jego koncepcja uruchomienia uczelni w totalnie zniszczonym mieście napotkała początkowo na opór ze strony nowych władz państwowych. Jednak upór Andrzeja Grodka doprowadził do uruchomienia Szkoły. Było to zadanie niezwykle skomplikowane. Przede wszystkim trzeba pamiętać, że w mieście nie było bieżącej wody, nie działały urządzenia kanalizacyjne, nie było prądu, nie istniała komunikacja miejska, a znaczna część ulic pozostawała nieprzejezdna ze względu na piętrzące się na jezdniach i chodnikach zwały gruzu ze zniszczonych domów. W mieście brakowało też jedzenia, a dla personelu nie było pieniędzy na wypłaty. Dodatkowo należało zabezpieczyć gmach Biblioteki przed złodziejami, stworzyć jakąś bazę noclegową dla powracających pracowników, opracować plany zajęć i zapewnić dla nich obsadę kadrową itd. Aktualny stawał się też problem odbudowy spalonego gmachu „A”, bez któ-

10 Druk [w:] Wybór..., t. II, s. 259-281. Jak wynika z noty wydawców: „Rozprawa ta [...] powstała w 1943 r. w ramach badań nad podstawami polityki gospodarczej po klęsce Niemiec hitlerowskich. Konspiracyjny maszynopis był anonimowy i nosił fałszywą datę 1939 r.”, tamże, s. 260.

11 Szerzej zob. A. Grodek, Biblioteka SGH po powstaniu. Strzęy wspomnień, „Gazeta Młodego Ekonomisty” 1956, nr 2. 
rego Szkoła nie dysponowała salami niezbędnymi do prowadzenia zajęć. Andrzej Grodek, przy współpracy z innymi pracownikami SGH, stopniowo doprowadził do rozwiązywania poszczególnych problemów, tak że już w końcu marca, w bardzo prymitywnych warunkach, Szkoła podjęła działalność dydaktyczną. Do tej idei udało się bowiem przekonać również władze państwowe.

W styczniu 1946 r. Andrzej Grodek, który w 1945 r. dostał nominację na profesora nadzwyczajnego, został jednomyślnie wybrany prorektorem Szkoły Głównej Handlowej, a we wrześniu 1947 r. rektorem. Społeczność akademicka miała przekonanie, że jest on najbardziej predysponowany do tej funkcji i że jest w stanie zapewnić Szkole wysoki poziom akademicki. Nowy rektor, który w momencie nominacji miał zaledwie 46 lat, bardzo sprawnie zarządzał uczelnią. Nie tylko doprowadził do uruchomienia zajęć, ale także zainicjował odbudowę gmachu „A” oraz uruchomienia oddziału w Łodzi. W związku z tym, że Szkoła poniosła w czasie wojny znaczne straty wśród personelu nauczającego, koniecznym stało się pozyskiwanie nowych pracowników. Andrzej Grodek starał się nie tylko o zatrudnianie znanych naukowców, ale też angażował ludzi, którzy w okresie wojny związani byli z podziemiem londyńskim i mogli napotkać na trudności w znalezieniu pracy. Stanisław Berezowski, który w czasie wojny pracował w Biurze Informacji i Propagandy Komendy Głównej Armii Krajowej pisał, że „to właśnie on [Andrzej Grodek] ułatwił mi znalezienie się w rzeczywistości Polski Ludowej"12 i zatrudnił go w 1946 r. w Szkole. Nie był to jedyny taki przypadek. W kierowanej przez siebie Katedrze Historii Gospodarczej zatrudniał na przykład na stanowisku asystenta dawnego członka Narodowych Sił Zbrojnych.

Grodek starał się nadać Szkole nowoczesny charakter akademicki. Nawiązywał tu do metod działania uczelni wypracowanych w okresie międzywojennym. Zdawał sobie chyba jednak sprawę, że stopniowo pogarszała się atmosfera wobec swobód naukowych i autonomii szkół wyższych. Władze polityczne i państwowe coraz silniej zaczęły dążyć do włączenia również szkół wyższych w system kształcenia kadr w oparciu o bardzo prymitywny model marksizmu. Stąd dążenie do wyeliminowania pracowników naukowych o odmiennych poglądach i dążenie do ich zastępowania przez kadry „nowej inteligencji ludowej”. Władzom zależało też na włączeniu szkół wyższych w system szybkiego szkolenia dużej liczby pracowników dla potrzeb gospodarki narodowej i innych segmentów państwa. Proces ten nasilił się wyraźnie w 1948 r. W tym okresie w Szkole Głównej Handlowej podjęto pewne przygotowania do funkcjonowania $\mathrm{w}$ zmieniającej się sytuacji. Polegały one na tym, aby co bardziej „trefnych” pracowników przenosić z katedr zaliczanych przez władze do grupy katedr ,ideologicznych” (np. ekonomia, filozofia, historia myśli ekonomicznej) do bardziej neutralnych komórek uczelni (np. biblioteka, katedry ilościowe). Trudno dziś ocenić, jaka w tym była rola ówczesnego rektora, ale te przesunięcia kadrowe nie mogły być dokonywane bez jego zgody.

W 1949 r. uczelnia została upaństwowiona i zmieniono jej nazwę na Szkoła Główna Planowania i Statystyki. Rektor Andrzej Grodek zastąpiony został przez

12 S. Berezowski, Rektor Andrzej Grodek..., s. 16. 
rektora z nominacji, którym mianowano zupełnie wcześniej nie związanego z SGH Czesława Nowińskiego. W tym okresie nastąpiła bardzo szybka ideologizacja Szkoły. Z programu usunięto wszystkie wykłady, które uważano za „burżuazyjne”, przy czym pojęcie to traktowano niezmiernie szeroko. Praktycznie „burżuazyjne” było wszystko co nie mieściło się w bardzo ortodoksyjnie ujmowanym marksizmie-leninizmie. Wprowadzono do uczelni również wielu nowych wykładowców; poziom naukowy był bardzo zróżnicowany. Z założenia Szkoła miała zostać nastawiona przede wszystkim na szkolenie urzędników dla potrzeb stale rozszerzającej się administracji gospodarczej. W związku z tym, że występował duży deficyt ekonomistów, wprowadzono początkowo trzyletnie studia dyplomowe, a następnie także dwuletnie magisterskie; taka struktura pozwalała kierować do pracy większość absolwentów już po trzech latach nauki. Szkoła z akademickiej przekształcała się w zawodową. Zmiany te nie były akceptowane przez większość starej kadry, ale nie miała ona żadnej możliwości przeciwstawienia się im. Trzeba przy tym pamiętać, że dawni pracownicy obawiali się utraty pracy ze względów ideologicznych.

Andrzej Grodek należał do niechętnie akceptujących wprowadzane reformy. Krytykował nie tylko zmiany programowe, ale również nową nazwę Szkoły13. Dla „starej” kadry nowe władze uczelni zorganizowały dokształcanie ideologiczne. W tym celu zimą 1949 r. zorganizowano specjalną konferencję w Kuźnicach, na której zwolennicy koncepcji marksistowskiej wygłaszali referaty mające przekonać do tej ideologii pozostałych profesorów. „Na początku konferencji Andrzej Grodek, który nie był już rektorem, ale nadal był największym autorytetem dla dawnego personelu, wysunął sugestię, abyśmy się próbowali w dyskusji przeciwstawiać najbardziej jaskrawym naruszeniom narzuconej nam sowieckiej wizji marksizmu. Ale na drugi dzień wycofał się z tego stanowiska. Najwyraźniej doszedł do przekonania, że nie doprowadzi to do niczego"14. Dla jasności należy stwierdzić, że Andrzej Grodek w wielu swych pracach posługiwał się metodologicznymi koncepcjami wywodzącymi się z marksizmu. Założenia tej doktryny filozoficznej i ekonomicznej były mu znane, gdyż obaj jego mistrzowie (Ludwik Krzywicki i Konstanty Krzeczkowski) byli w jakimś stopniu marksistami.

Andrzej Grodek po odsunięciu od administracji Szkoły, skupił się na działalności w Katedrze Historii Gospodarczej SGPiS oraz na własnej pracy badawczej. Działał też w organizacji bibliotekarzy. Prace naukowe dotyczyły problemów polskiej postępowej myśli finansowej epoki feudalizmu i kapitalizmu, postępowej tradycji nauk handlowych, sytuacji historii myśli ekonomicznej w Polsce, historii Warszawskiego Domu Handlowego w latach 1723-1724, archiwalii gospodarczych i zasad ich wykorzystywania w badaniach naukowych. Pisał też kolejne edycje skryptu z historii gospodarczej. Badanie te były w zasadniczym nurcie tradycyjnych zainteresowań ich autora. Pewnego rodzaju oderwaniem od codzienności była praca nad poglądami Jana Kantego Podoleckiego, ekonomisty i polityka związanego z centralizacją, piszącego w latach 1846-1851. Pozostawił on po sobie niewielką

13 M.W. Mróz, Andrzej Grodek..., [w:] Poczet..., s. 44.

14 J. Drewnowski, Autobiografia, „Kwartalnik Historii Nauki i Techniki” 1990, nr 5, s. 451-489. 
liczbę podpisanych publikacji o charakterze socjalistycznym. Andrzej Grodek starał się odnaleźć i inne - niesygnowane - jego prace. Czytał wiec ogromną liczbę różnorodnych publikacji, aby wybrać z nich te, które i treścią i stylem odpowiadały znanym publikacjom Jana Kantego Podoleckiego. Była to w pewnym stopniu zabawa intelektualna, gdyż szukanie polegało na stosowaniu pewnego rodzaju śledztwa naukowego. Wyniki pracy zostały ogłoszone w odrębnej książce ${ }^{15}$.

Duże znaczenie Andrzej Grodek przywiązywał do funkcjonowania Katedry Historii Gospodarczej. W tym okresie przyjmowano bardzo wielu zastępców asystentów (było wówczas takie stanowisko), a więc studentów po pierwszym czy drugim roku studiów. Chodziło bowiem o to, aby możliwie jak najszybciej poważnie zwiększyć liczbę pracowników naukowych, i żeby ci reprezentowali już ideologię marksistowską. W Katedrze o przekonanie do marksizmu nie dbano, natomiast koncentrowano się na zaznajamianiu młodych adeptów nauki z historią gospodarczą, metodami pracy naukowej, pisaniem recenzji i artykułów. Andrzej Grodek był szefem wymagającym. Każdemu asystentowi stawiał konkretne zadania naukowe i dbał o ich realizację. Jeżeli ktoś nie dawał sobie rady z przyczyn merytorycznych czy wyraźnego braku zdolności do pracy naukowej, to szef Katedry rezygnował z dalszej z nim współpracy, ale starał się o zapewnienie delikwentowi jakiegoś innego miejsca zarobkowania. Jeżeli ktoś natomiast nie wywiązywał się z zadań, bo mu się po prostu nie chciało, to żegnał Katedrę bez nowego miejsca pracy. W Szkole nie obowiązywały wówczas jeszcze pensa dydaktyczne, plany naukowe, okresy wypowiedzenia pracy asystentowi dopiero po ośmiu latach od chwili zatrudnienia, awanse płacowe uzależnione od uzyskiwanych stopni naukowych itd. Kierownik Katedry miał tu znacznie większe uprawnienia niż obecnie; jak ktoś mu nie odpowiadał, to w każdej chwili mógł wystąpić o zwolnienie, przy tym asystenci byli angażowani do różnych prac naukowych wykonywanych przez ich szefa czy starszych kolegów. W ten sposób szybko wprowadzani byli w tryb pracy naukowej. Pomagali w zbieraniu materiałów, czasami pisali fragmenty skryptów, chodzili na wykłady, brali udział w często odbywających się naukowych zebraniach Katedry, uczestniczyli w egzaminach. Andrzej Grodek wprowadził zwyczaj, że wszystkie prace pisane przez młodszych pracowników, przed publikacją, były mu przedstawiane do zatwierdzenia. Był bardzo uważnym czytelnikiem, czasami sugerował jakieś zmiany, ale z reguły akceptował poglądy autora, nawet jeżeli się $\mathrm{z}$ niemi nie zgadzał. Jako promotor prac doktorskich miał zasłużoną opinię wymagającego i trudnego. Niełatwo było go bowiem zadowolić i po kilka razy potrafił zmieniać konstrukcję i koncepcję rozprawy.

W 1952 r. sytuacja Andrzeja Grodka nieco się zmieniła. Nowym rektorem został wybitny ekonomista Oskar Lange, który jednak traktował swą funkcję w SGPiS jako zesłanie i praktycznie mało interesował się sprawami uczelni. Prawdopodobnie dlatego na stanowisko prorektora do spraw nauki powołano Andrzeja Grodka. Znał Szkołę, jej problemy, ludzi. Jego nominacja pozwalała Langemu na odcią-

15 A. Grodek, Jan Kanty Podolecki. Wybór pism z lat 1846-1854, Warszawa 1955, PWN, s. LXXVII, 302. 
żenie się od wielu nielubianych czynności, które go po prostu nie interesowały. Nowy prorektor miał pewne opory przed przyjęciem stanowiska, ale ostatecznie uznał, że może mieć jakiś wpływ na to, co się w Szkole będzie działo. Nowe stanowisko administracyjne nie wpłynęło na rezygnację z pracy naukowej. W tym okresie do tradycyjnych zainteresowań myślą ekonomiczną i historią gospodarczą doszły studia nad początkami rozpowszechniania się koncepcji marksistowskich w Polsce ${ }^{16}$. Były to opracowania bardzo rzeczowe, wolne od zbędnej ideologii. Prawdopodobnie ten nurt badań miał na celu ochronę autora przed zarzutem ulegania wpływom „burżuazyjnym” i unikania tematów dotyczących marksizmu. Ciekawe, że po 1953 r. ta problematyka już się nie pojawiała w pracach Andrzeja Grodka. Prawdopodobnie wynikało to z pewnej liberalizacji polityki naukowej po śmieci Józefa Stalina. W tym okresie większą uwagę przywiązywał do studiów nad początkami gospodarki kapitalistycznej na ziemiach polskich. Zainicjował swymi publikacjami interesującą dyskusję na ten temat. Dowodził, że kapitalizm w rolnictwie ziem polskich zaczął na większa skalę rozwijać się dopiero w ostatnim dwudziestoleciu XIX wieku, a nie jak twierdzili jego polemiści już w pierwszej połowie tego stulecia.

Zmiany jakie dokonały się w Polsce po śmierci Józefa Stalina odcisnęły swój wpływ również na funkcjonowaniu SGPiS. W 1955 r. Andrzej Grodek mianowany został rektorem Szkoły. W 1956 r. Senat jednomyślnie powołał go na to stanowisko na lata 1956/57 - 1958/59. W tym okresie zrodziła się szansa na podniesienie poziomu nauczania na uczelni, jak też na rozwój nauk ekonomicznych w kraju. Ale możliwości mogą być wykorzystane, albo zmarnowane. Nowy rektor starał się wykorzystać powstałe możliwości. Wymagało to jednak pewnych zmian kadrowych na uczelni. Andrzej Grodek starał się, aby zmiany te dokonywały się w jak najmniejszym stopniu kosztem pracowników. Dlatego po likwidacji katedry marksizmu-leninizmu, jej licznym pracownikom stworzył szanse zatrudnienia w innych jednostkach naukowych uczelni. Istniejące katedry nie były jednak w stanie wchłonąć wszystkich pracowników zatrudnionych w likwidowanych zakładach. Dlatego rektor podjął starania o reaktywowanie, w ramach Szkoły Głównej Planowanie i Statystyki, przedwojennego Instytutu Gospodarstwa Społecznego. Nowa placówka miała koncentrować się na badaniu zjawisk społecznych, a równocześnie stworzyć dodatkowe miejsca pracy ${ }^{17}$. Wobec pewnego przewlekania się formalności związanych z utworzeniem Instytutu, powołał do życia w SGPiS zakłady: zagadnień społecznych, ekonomiki i prawa pracy oraz turystyki. W ramach prowadzonej polityki kadrowej starał się przywracać profesorom, którzy w poprzednim okresie

16 M.in.: A. Grodek, Znajomość dzieł Marksa w Polsce przed $1876 r$. Głos w dyskusji, [w:] Sesja naukowa poświęcona trzeciemu polskiemu wydaniu I tomu „Kapitału” K. Marksa, Warszawa 1952, s. 289-294; Pierwsze czasopisma marksistowskie a wspótczesna im prasa polska, „Prasa Polska” 1953, nr 2, s. 26-27; Pierwsze polskie przekłady [dzieł K. Marksa], „Świat” 1954, nr 18, s. 10; W kwestii związów między Marksem a Polakami w latach 1847-1883, „Zeszyty naukowe SGPiS” 1953, nr 1, s. 5-33; Znajomość dziet Marksa w Polsce przed r. 1883, „Ekonomista” 1953, nr 2, s. 33-48.

17 Szerzej zob. H. Balicka-Kozłowska, Andrzej Grodek... 
zostali pozbawieni stanowisk, ich katedry i zakłady. Trzeba jednak pamiętać, że rektor w swych działaniach był poważnie ograniczony zarówno przez istnienie centralnego planowania, które m.in. określało wielkości naboru studentów na studia na poszczególnych wydziałach, liczbę pracowników itd., jak też w wyniku istnienia w SGPiS bardzo silnej organizacji Polskiej Zjednoczonej Partii Robotniczej. Praktycznie każda decyzja rektora wymagała zgody egzekutywy organizacji partyjnej. W okresie „odwilży” PZPR w większym stopniu było skłonne do pewnych kompromisów i dzięki temu bezpartyjny rektor miał większą swobodę działania. Pewnym paradoksem było to, że na korzyść Andrzeja Grodka działało to, że nie należał do PZPR. Nie można Mu bowiem było dawać wiążących poleceń partyjnych.

Andrzej Grodek uważał, że nie tylko SGPiS wymagało przemian, ale że dotyczyło to całego polskiego wyższego szkolnictwa ekonomicznego. Dlatego włączył się do prac sekcji ekonomicznej Rady Głównej Szkolnictwa Wyższego i został jej przewodniczącym, co ułatwiało mu realizację własnych koncepcji reform. Ich wstępny zarys dla Szkoły przedstawił w opracowaniu: „Szkoła Główna Planowania i Statystyki w planie pięcioletnim"18 oraz w przemówieniu na inauguracji roku akademickiego 1956/57.

W pierwszym wystąpieniu wskazywał na potrzebę podniesienia prestiżu Szkoły m.in. poprzez podnoszenie kwalifikacji pracowników naukowych i dydaktycznych. Uważał, że należy zlikwidować grupę zastępców asystentów, i że warunkiem uzyskania asystentury winno być posiadanie magisterium. Ustosunkował się też do dość licznej grupy zastępców profesorów, a więc osób nie mających formalnych kwalifikacji dla uzyskania tytułu profesora. W stosunku do nich postulował, aby uzyskali stopnie kandydata nauk (ten stopień na wzór ZSRR zastępował stopień doktora). Dalej wskazywał na konieczność rozwoju badań naukowych.

W przemówieniu inauguracyjnym m.in. wyliczył osiągnięcia szkolnictwa ekonomicznego w poprzednich latach (większy dostęp do studiów młodzieży robotniczej i chłopskiej, silniejsze powiązanie nauczania z praktyką gospodarczą, oparcie nauczania na zasadach marksizmu, zwiększenie liczby studentów i pracowników naukowych). Ale już w następnym zdaniu po pochwałach stwierdził: „w zapale rewolucyjnych przemian uległo wówczas zniszczeniu wiele $\mathrm{z}$ cennego dorobku Szkoły"19. Do strat zaliczył zbytnią technizację studiów, likwidację seminariów obowiązujących przed wojną wszystkich studentów, zaniedbanie nauczania języków obcych czy wprowadzenie nazbyt wąskich specjalizacji. „O ile słusznym było wprowadzenie wykładów specjalizacyjnych, nawet bardzo wąskich, to błędem było wprowadzanie wąskich kierunków nauczania i specjalizacji zawodowej”. Przygotowywana reforma miała w skali kraju przywrócić akademicki charakter kształcenia ekonomistów. „Zadaniem studiów ma być nie tylko danie gruntownej

18 Konspekt przemówienia SGPiS na naradzie profesorów i aktywu szkolnego w dn. 28 lutego $1956 \mathrm{r}$.

19 Tekst [w:] „Zeszyty Naukowe SGPiS” 1957, nr 5, s. 4. Dalsze cytaty pochodzą z tego przemówienia. 
znajomości głównego przedmiotu studiów, ale również wyrobienie wśród studentów sprawności i samodzielności myślenia w zakresie przedmiotu studiów". Nadanie studiom charakteru akademickiego wymagało „zerwania z metodą szkolenia połączoną z powierzchowną dyscypliną studiów". Zmuszało natomiast do zwiększania własnej pracy studenta. Andrzej Grodek stwierdzał dalej - co dziś mogłoby się nie podobać - że Ministerstwo Szkolnictwa Wyższego nie powinno mieć prawa do ustalania programów nauczania w szkołach wyższych. „W odróżnieniu od szkoły średniej program nauczania i poglądy na dane zagadnienie w szkole wyższej są autonomiczną sprawą profesora. Uzyskanie venia legendi oznacza przecie nie prawo uczenia, ale prawo wykładania wyników swoich badań". A więc rektor w tej formie akcentował prawo do głoszenia w szkołach wyższych pluralistycznych poglądów, a nie tylko koncepcji marksistowskich. Dalej podkreślał znaczenie badań naukowych, które w zakresie ekonomii w poprzednich latach prawie całkowicie upadły. Postulował też istotną zmianę formuły studiów zaocznych, uważając aktualnie obowiązującą za całkowicie niedostosowaną do potrzeb nowoczesnego nauczania. Uważał, że i na tych studiach winno wprowadzać się seminaria, gdyż stwarzały one większe możliwości rozwoju intelektualnego słuchaczy.

We wrześniu 1958 r. przedstawił „Projekt nowej organizacji Szkoły”20. W programie tym wyszedł z założenia, że kształcenie ekonomistów w szkołach wyższych należy wyraźnie zróżnicować. Winny być szkoły o profilu akademickim, z dłuższym okresem nauki, kształcące pracowników o charakterze sztabowym, i odrębne wyższe szkoły zawodowe nastawione na kształcenie niższego personelu ekonomicznego - księgowych, planistów, pracowników aparatu bankowego, referentów itd. w cyklu dwóch-trzech lat. Na studia zawodowe winne być kierowane też osoby pracujące. SGPiS miała zachować charakter szkoły akademickiej, ale w trybie zaocznym prowadzić zajęcia o profilu zawodowym (ale nie akademickim). Andrzej Grodek nie ukrywał, że tylko pewna część młodzieży nadaje się na studia o charakterze akademickim; pozostali powinni ograniczać się do studiów zawodowych. Swoje stanowisko formułował na podstawie analizy danych o liczbie osób, które zaczynały i kończyły wyższe studia ekonomiczne. Przed wojną zaledwie $1 / 3$ immatrykulowanych studentów uzyskiwała dyplom SGH; pozostali odpadali, gdyż nie dawali sobie rady.

Andrzej Grodek był też zwolennikiem rozszerzenia profilu Szkoły. „Obecnie - pisał w 1958 r. - wszystkie sześć wydziałów Szkoły to wydziały ekonomiczne. Uważam, że jest to dla naszej Szkoły profil zbyt wąski. W szczególności Wydział Handlu Zagranicznego nie powinien ograniczać się do problematyki ekonomicznej, ale powinien objąć problematykę międzynarodową, polityczną i prawną, w obecnych bowiem warunkach trudno oderwać ekonomikę krajów kapitalistycznych od polityki”. Postulował, aby Szkoła była tylko dwuwydziałowa - Wydział Ekonomiczny nastawiony byłby na kształcenie specjalistów dla gospodarki socjalistycznej, natomiast Wydział Zagraniczny na specjalistów od handlu zagranicznego, innych dziedzin stosunków międzynarodowych i kontaktów z zagranicą.

20 Maszynopis powielany w Bibliotece SGH nr 38934. 
Były to już ostatnie propozycje Andrzeja Grodka dotyczące organizacji SGPiS. Kiedy je pisał wiedział, że jest śmiertelnie chory. Śmierć rektora prawdopodobnie spowodowała, że jego projekty nie zostały zrealizowane. Następni rektorzy mieli bowiem inne koncepcje organizacji Szkoły. Zmieniała się też atmosfera w kraju. Stopniowo wprowadzano znów odgórne regulacje i ograniczano samodzielność poszczególnych instytucji. Dotyczyło to i szkolnictwa wyższego.

Ale jeszcze w 1958 r. Andrzej Grodek podjął polemikę z ministrem szkolnictwa wyższego na temat roli i perspektyw nauk ekonomicznych w Polsce. Pisał m.in. „chyba wszyscy zgodnie stwierdzimy, że nauki ekonomiczne i szkoły ekonomiczne powinny zajmować się nade wszystko naszą polską rzeczywistością. Czyżby było inaczej? Niestety, tak. Nauki ekonomiczne i szkoły ekonomiczne nie zajmowały się naszą rzeczywistością, lecz - źle rozumiejąc potrzeby Polski Ludowej (na to się wszyscy dzisiaj zgadzają, że były to potrzeby źle zrozumiane) - zajmowały się nie tym, co jest, ale tym, co w fałszywym zrozumieniu doktryny powinno być. Zamiast też mówić o faktach, mówiło się o programach, uchwałach, ustawach, rozporządzeniach itd. Jeżeli zaś podawało się fakty, to tak drobne, aby te programy i ustawy one potwierdzały. Fakty, które nie były w zgodzie z zaleceniami i uchwałami, uważano za wypaczenia: traktowano je nie jako wynik naturalnych praw ekonomicznych, lecz jako przejaw destrukcyjnej roboty elementów wrogich, obcych agentur itd. Uważano, że są to sprawy podlegające rozpatrzeniu nie ekonomii, ale raczej kodeksu karnego. Że tak było, wystarczy zajrzeć do prac i podręczników ekonomii politycznej i ekonomik". Z tego wyciągał wniosek: „absolwent szkoły ekonomicznej, aby być pożytecznym naszej gospodarce, powinien znać problematykę rzeczywistą, powinien ją umieć rozwiązywać. Inaczej będzie z niego tylko biurokrata, który zna życie z uchwały, dekretów i rozporządzeń, który wie jak ma być, który zna akta, lecz nie fakty. Takiego ekonomisty nasze życie nie potrzebuje. I szkół kształcących takich biurokratów również nie potrzeba"21. Był to w pewnym stopniu testament Andrzeja Grodka. Senat SGPiS oceniając jego rolę w życiu uczelni, w czerwcu 1958 r. uroczyście stwierdził, że „rektor profesor Grodek dobrze zasłużył się Szkole”.

Dla rektora była to wysoka nagroda za to, że Szkoła leżała w centrum jego zainteresowań. W momentach kiedy miał wpływ na działalność uczelni słabło jego zainteresowanie własnymi badaniami naukowymi. Prawdopodobnie wynikało to z czasochłonności zajęć administracyjnych. Ale nawet $\mathrm{w}$ takich okresach nie zaniedbywał prowadzenia studiów. Przed wojną - jak wydaje się - ciężar zainteresowań kierował się bardziej ku historii myśli ekonomicznej. Problematyka historii gospodarczej była mu wówczas dalsza. Poświęcał jednak sporo uwagi problemom metodologii badań historyczno-gospodarczych. Ogłosił artykuł pt. „Czego historią

21 A. Grodek, O wyższych szkołach ekonomicznych, „Życie Szkoły Wyższej” 1958, nr 3, s. 17 i 19. 
jest historia gospodarcza"22. Podjął też prace nad uprawianiem geografii, ale nie zostały one zakończone ${ }^{23}$.

Przed wybuchem wojny w 1939 r. ogłosił drukiem w Encyklopedii Nauk Politycznych i Polskim Słowniku Biograficznym kilkadziesiąt biografii ekonomistów i działaczy gospodarczych. Były to na ogół prace krótkie, ale ich przygotowanie wymagało ogromnego nakładu pracy i wielkiej erudycji. W artykułach biograficznych autor zawsze musi ustalić wiele szczegółów (datę urodzenia, śmierci, przebieg i formy działalności, publikacje itd.), gdyż wymaga tego przyjęta konwencja publikacji haseł encyklopedycznych. Czasami zaś ustalenie jakiejś daty może wymagać rozległych poszukiwań i zakończyć się stwierdzeniem, że w literaturze i dokumentach występują różne daty dotyczące tego samego wydarzenia. W tej sytuacji należy dokonać ich weryfikacji. Szczególne trudności nasuwają się, gdy piszemy o osobie mniej znanej, o której literatura na ogół milczy. Wiele życiorysów pisanych przez Andrzeja Grodka zapewniło zachowanie na zawsze informacje o czyimś działaniu i życiu. Po drugiej wojnie niektórych biografii opartych o archiwalia nie dałoby się już napisać. Wiele tych opracowań zawierało nowe ustalenia faktów i nowe opinie o opisywanych ludziach. Przykładem mogą być biografia Jana Gotliba Blocha ${ }^{24}$ czy Ferdynanda Jana Naxa ${ }^{25}$. Grodek publikował też - poza już wcześniej wymienionymi - większe prace z zakresu historii polskiej myśli ekonomicznej, jak np. artykuł o Katedrze Ekonomii w Wilnie w latach 1803-183126 czy o poglądach i życiu księdza Piotra Świtkowskiego w końcu XVIII wieku $^{27}$. Pisał też wiele recenzji z książek.

Po drugiej wojnie światowej większe jego zainteresowanie zaczęła budzić historia gospodarcza. Może było to związane z dążeniem do napisania podręcznika historii gospodarczej dostosowanego do potrzeb studentów wydziałów ekonomicznych. Takich podręczników w tym okresie właściwie nie było, poza bardzo tradycyjnie opisowym opracowaniem Jana Rutkowskiego. Andrzej Grodek napisał więc artykuł „O rozwoju kapitalizmu na Górnym Śląsku”28, „O rozwoju kapitalizmu w rolnictwie Królestwa Polskiego. Uwagi krytyczne"29 i w ramach podręcznika Historii Polski opracowywanego przez Instytut Historii PAN rozdział pt. „Stosunki gospodarczo-społeczne po reformie uwłaszczeniowej w Królestwie Polskim i w okręgu białostockim"30. Jak już wspomniano celem tych publikacji było ustalenie momentu powstania gospodarki kapitalistycznej na ziemiach polskich.

22 Pamiętnik trzydziestolecia Szkoły Głównej Handlowej w Warszawie 1906-1936, Warszawa 1938, s. $46-62$.

23 A. Grodek, O geografii jako nauce, [w:] Wybór..., t. II, s. 36-53.

24 Polski Słownik Biograficzny, t. II.

25 Encyklopedia Nauk Politycznych, t. IV.

26 „Ekonomista” 1933, nr 1, s. 32-46.

27 „Roczniki Dziejów Społecznych i Gospodarczych” 1934, s. 199-212.

28 „Przegląd Zachodni” 1948, nr 4, s. 356-381.

29 VIII Powszechny Zjazd Historyków Polskich w Krakowie. Referaty i dyskusja. VI. Historia gospodarcza Polski, Warszawa 1960, s. 263-277.

30 Historia Polski, t. III, cz. I - 1850/1864-1900. Makieta, Warszawa 1960, s. 285-308. 
Zresztą i poglądy autora na ten temat ewoluowały. Gdy przed wojną zajmował się instytucjami finansowymi, to początki kapitalizmu w Królestwie Polskim datował na lata dwudzieste XIX wieku. Gdy jednak rozpoczął badania nad rozwojem kapitalizmu w dominującym dziale ówczesnej gospodarki - w rolnictwie stwierdził, że kapitalizm w Królestwie pojawił się znacznie później31.

Trudno nie zgodzić się z poglądem wyrażonym przez Witolda Kulę, że: „w pracy naukowej Andrzeja Grodka znajduje rzadko spotykane szczęśliwe połączenie szerokości horyzontów z drobiazgowością analizy, prymat ekonomicznego problemu i urok historycznego szperactwa. Przedwczesna śmierć, a za życia ogrom obowiązków i funkcji społecznych nie pozwoliły mu wykonać wielu z szerszych planów naukowych"32.

\section{ANDRZEJ GRODEK (1901-1959)}

\section{Summary}

Andrzej Grodek's life revolved around the Warsaw School of Economics. He studied at SGH and became a teacher after graduation. He worked as deputy manager and subsequently manager of the school library. He then was a professor and head of the Economic History Faculty only to become a pro-rector and finally rector. His main idea was to maintain the original character of the school, which was especially important in 1949-1956 when the school's profile was modified to suit the educational priorities of the communist government. After the political thaw of 1956, Grodek, as rector, made successful efforts to restore the school's original academic character. In addition to his achievements as the school's manager, Grodek was an eminent economic historian and a researcher of the Polish economic thought of the $18^{\text {th }}$ and $19^{\text {th }}$ centuries. His pursued an extensive range of research interests and published many analytical and descriptive works on the history of economic theory and synthetic studies of economic history. These works contributed new ideas to our knowledge about the history of the Polish economy. Grodek's interests also included the methodology of economic research.

31 Szerzej zob. I. Kostrowicka, Andrzej Grodek..., s. 3-7.

32 W. Kula, Andrzej Grodek..., s. 1391. 